\title{
BMJ Open Preventive zinc supplementation for children, and the effect of additional iron: a systematic review and meta-analysis
}

\author{
Evan Mayo-Wilson, ${ }^{1}$ Aamer Imdad, ${ }^{2}$ Jean Junior, ${ }^{3}$ Sohni Dean, ${ }^{4}$ Zulfiqar A Bhutta ${ }^{5,6}$
}

To cite: Mayo-Wilson E, Imdad A, Junior J, et al. Preventive zinc

supplementation for children and the effect of additional iron: a systematic review and meta-analysis. BMJ Open 2014;4:e004647. doi:10.1136/ bmjopen-2013-004647

- Prepublication history and additional material is available. To view please visit the journal (http://dx.doi.org/ 10.1136/bmjopen-2013004647).

Received 9 December 2013 Revised 13 May 2014 Accepted 14 May 2014

CrossMark

For numbered affiliations see end of article.

Correspondence to Professor Zulfiqar A Bhutta; zulfiqar.bhutta@sickkids.ca

\section{ABSTRACT}

Objective: Zinc deficiency is widespread, and preventive supplementation may have benefits in young children. Effects for children over 5 years of age, and effects when coadministered with other micronutrients are uncertain. These are obstacles to scale-up. This review seeks to determine if preventive supplementation reduces mortality and morbidity for children aged 6 months to 12 years.

Design: Systematic review conducted with the Cochrane Developmental, Psychosocial and Learning Problems Group. Two reviewers independently assessed studies. Meta-analyses were performed for mortality, illness and side effects.

Data sources: We searched multiple databases, including CENTRAL and MEDLINE in January 2013. Authors were contacted for missing information.

Eligibility criteria for selecting studies:

Randomised trials of preventive zinc supplementation. Hospitalised children and children with chronic diseases were excluded.

Results: 80 randomised trials with 205401 participants were included. There was a small but non-significant effect on all-cause mortality (risk ratio (RR) $0.95(95 \% \mathrm{Cl} 0.86$ to 1.05$))$. Supplementation may reduce incidence of all-cause diarrhoea (RR 0.87 (0.85 to 0.89)), but there was evidence of reporting bias. There was no evidence of an effect of incidence or prevalence of respiratory infections or malaria. There was moderate quality evidence of a very small effect on linear growth (standardised mean difference $0.09(0.06$ to 0.13$)$ ) and an increase in vomiting (RR 1.29 (1.14 to 1.46)). There was no evidence of an effect on iron status. Comparing zinc with and without iron cosupplementation and direct comparisons of zinc plus iron versus zinc administered alone favoured cointervention for some outcomes and zinc alone for other outcomes. Effects may be larger for children over 1 year of age, but most differences were not significant. Conclusions: Benefits of preventive zinc supplementation may outweigh any potentially adverse effects in areas where risk of zinc deficiency is high. Further research should determine optimal intervention characteristics and delivery strategies.

\section{INTRODUCTION}

Regular dietary zinc intake is required because zinc cannot be produced or

\section{Strengths and limitations of this study}

- This large review was conducted according to best practices and includes the highest quality current evidence about the effects of zinc supplementation.

- We investigated several outcomes and made multiple comparisons to explore the most important main effects and interactions.

- The analyses in this review could not identify the best way to deliver zinc supplements to children in need.

stored. ${ }^{12}$ In 2011, 116000 deaths in children under 5 years were attributable to zinc deficiency (1.7\% of mortalities in this group). ${ }^{3}$

Previous reviews have reached disparate conclusions about the benefits of zinc supplementation for young children, ${ }^{4-12}$ and most have not examined evidence for children over 5 years of age. Zinc deficiency is prevalent in areas with other micronutrient deficiencies. Concerns about the administration of zinc with iron have been an obstacle to widespread delivery. ${ }^{13}$ Understanding the effects of preventive zinc supplementation alone and with iron is crucially important to the future of global health policy.

To evaluate the effects of zinc with or without iron on illness and mortality, as well as growth, we analysed direct comparisons (ie, zinc plus iron vs zinc alone) as well as subgroups within an overall analysis.

\section{METHODS}

Selection criteria and search strategy

Following a published protocol, ${ }^{14}$ we conducted a systematic review of randomised clinical trials of orally administered zinc compared with placebo and non-zinc cointerventions received by both groups (eg, vitamin A). We also compared zinc with and without iron cosupplementation. Participants were 6 months to 12 years of age. We excluded 
studies of food fortification and children who were acutely ill.

We searched the African Index Medicus, CENTRAL, Conference Proceedings Citation Index, EMBASE, Global Health, ICTRP, IndMED, LILACS, MEDLINE, metaRegister of Controlled Trials, ProQuest Dissertations \& Theses Database and WHOLIS in December 2012 and January 2013 (see online supplementary appendix 1). Reference lists from previous reviews and from included studies were examined, and trial authors were contacted for unpublished data. Two authors independently reviewed citations and extracted data, including participant demographics, details of the intervention, outcomes and risk of bias. ${ }^{15}$

\section{Data synthesis}

Relative risks and 95\% CIs were calculated using Mantel-Haenszel methods. Standardised mean differences (SMDs) and 95\% CIs were calculated for continuous measures using Hedges $\mathrm{g}$ and combined using inverse variance methods. When studies reported data in multiple formats, we calculated the SMD and its SE in Comprehensive Meta-Analysis (CMA) V.2 before entering data in Review Manager (RevMan) V.5.2. For incidence data, we combined risk ratios (RR) (events per child) and rate ratios (events per child year) because trials were relatively short and we did not anticipate interactions between the intervention and time at risk. For cluster-randomised trials, we used effects controlling for clustering, or we used a intracluster correlation coefficient to estimate robust SEs. ${ }^{15}$ We used fixed-effect methods for all meta-analyses. Effects favour intervention when the relative risk is reduced $(R R<1)$ or the standardised difference is positive $(\mathrm{SMD}>0)$.

When 10 or more studies reported an outcome, we conducted subgroup analyses to explore the effects of iron cosupplementation, national income (low-income countries compared with others), stunting, age (6-12, more than 12 months), dose $(0-5,5-10 \mathrm{mg}$, etc), duration (0-6, 6-12, more than 12 months) and formulation.

\section{Quality of the evidence}

Quality of the evidence was judged independently using GRADE. ${ }^{16}$ The GRADE system rates evidence from each analysis (ie, pooled data where possible) as 'high', 'moderate', 'low' or 'very low'. A 'high' rating suggests that evidence is unlikely to be affected by further studies; a 'low' rating suggests that further research is required to confirm the direction and magnitude of the true effect. Ratings for meta-analyses of randomised controlled trials start at 'high' and may be downgraded for threats to internal validity (ie, within-study bias), inconsistency (ie, heterogeneity in results across studies), indirectness (eg, measures are proxies for the true outcome of interest), imprecision (eg, few participants, wide CIs) and reporting bias (ie, publication bias and selective outcome reporting). Because GRADE considers several domains in addition to internal validity, confidence in overall effects may be 'low' or 'very low' even when all studies are conducted rigorously. The following sections include significant and non-significant statistical results, and GRADE ratings in the text and tables provide further information about our confidence in these estimates.

\section{RESULTS}

\section{Results of the search}

From 6384 records, 80 studies were included (figure 1). Seventy-five studies were published in English, two each in Spanish and Portuguese and one in Chinese. Reasons for excluding 27 studies were enumerated (see online supplementary appendix 2); additionally, 11 ongoing studies were identified, and 5 studies could not be obtained. Seven included studies did not contribute to any meta-analysis because they did not report sufficient data (see online supplementary appendix 3 ).

\section{Study characteristics}

Included studies assigned 205923 eligible participants (see online supplementary appendix 4). Twenty trials used factorial designs; there were 100 independent comparisons isolating zinc, and cointerventions were provided to both groups in 51 comparisons. There were eight independent comparisons of iron with zinc versus zinc alone including 1898 eligible participants. Sample sizes ranged from 21 to 72438 eligible participants (median=200). Nine studies were cluster-randomised, including two randomising households. Three studies included $88 \%$ of participants. ${ }^{17-19}$ Forty-six studies reported the mean baseline plasma or serum zinc concentration of their participants; the median of these mean concentrations was $72.5 \mu \mathrm{g} / \mathrm{dL}$.

Thirty-two countries are represented; most studies were conducted in low-income or middle-income countries: 37 in Asia, 26 in Latin America and the Caribbean and 10 in sub-Saharan Africa. The median of mean age at baseline was 28 months, and 22 studies included children over 5 years of age. Stunted and non-stunted children were included in 42 studies; 5 included only stunted children, 5 included only non-stunted children and 28 did not specify if participants were stunted.

Studies provided zinc for less than 6 (30), 6-12 (33) and 12 months or more (16). Of those reporting frequency of zinc supplementation, 48 provided zinc daily and 11 provided zinc weekly. Where reported, daily dose was $0-5$ (5), 5-10 (19), 10-15 (30), 15-20 (8) and $20 \mathrm{mg}$ or more (12). Studies reporting the chemical compound of their zinc supplements provided zinc as sulfate (45), gluconate (12), acetate (6) and other compounds (8). Studies comparing zinc with iron versus zinc alone provided daily dose equivalents of 3-36 $\mathrm{mg}$ of iron. Outcomes were observed for about 26 weeks (median) after randomisation, with follow-up from 2-80 weeks. 
Figure 1 PRISMA flow chart.

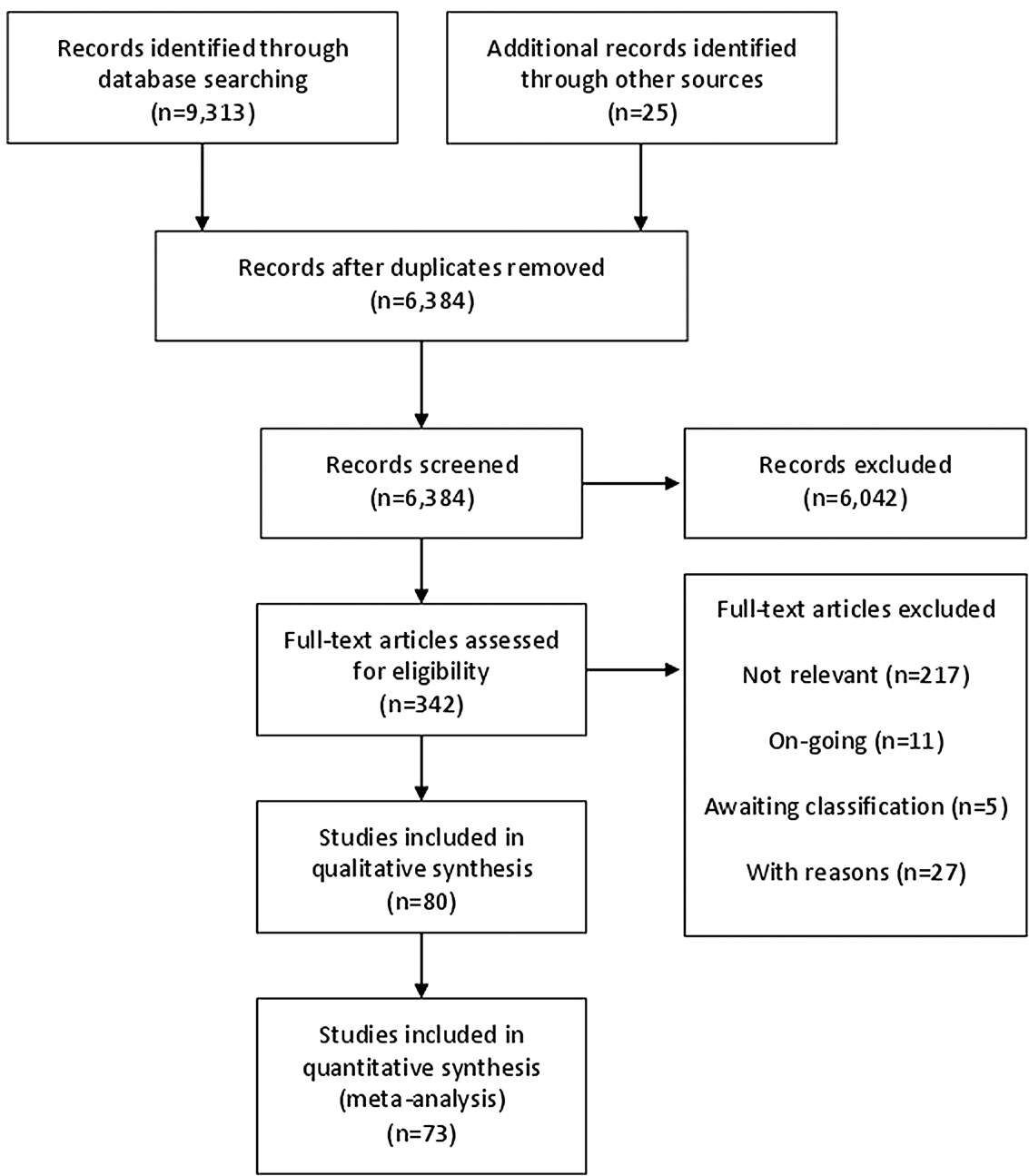

\section{Risk of bias}

Randomisation and allocation concealment were adequate in 34 and 32 studies; 46 and 48 studies were unclear (figure 2). For blinding of participants and personnel, 63 studies were at low risk of bias. For blinding of outcome assessment, 65 studies were at low risk of bias. For both types of blinding, 15 studies were unclear.

For all analyses, we attempted to include all randomised study participants; 47 studies were at low risk of
Figure 2 Risk of bias summary.

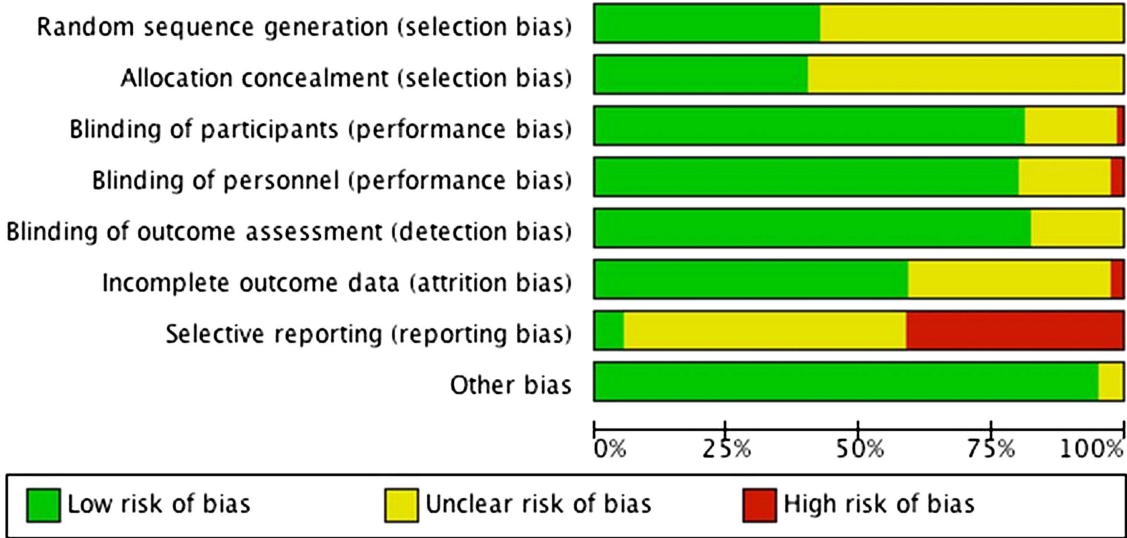

bias for incomplete data, 31 were unclear and 2 were at high risk. For selective reporting, 3 studies were at low risk of bias, 44 were at unclear risk and 32 were at high risk (see online supplementary appendix 5).

Bias may affect secondary outcomes in this review, but it does not appear to be important for the primary outcome. For example, mortality and other objective measures are not vulnerable to bias related to blinding, and many missing outcomes were biomarkers or growth related. 


\begin{tabular}{|c|c|c|c|c|c|}
\hline \multirow[b]{2}{*}{ Outcomes } & \multicolumn{2}{|c|}{ Illustrative comparative risks* $(95 \% \mathrm{Cl})$} & \multirow[b]{2}{*}{ Relative effect $(95 \% \mathrm{Cl})$} & \multirow[b]{2}{*}{$\begin{array}{l}\text { Number of participants } \\
\text { (studies) }\end{array}$} & \multirow{2}{*}{$\begin{array}{l}\text { Quality of the } \\
\text { evidence } \\
\text { (GRADE) }\end{array}$} \\
\hline & $\begin{array}{l}\text { Assumed risk } \\
\text { Control }\end{array}$ & $\begin{array}{l}\text { Corresponding risk } \\
\text { Zinc }\end{array}$ & & & \\
\hline $\begin{array}{l}\text { All-cause mortality } \\
\text { Follow-up: } 17-72 \text { weeks }\end{array}$ & $\begin{array}{l}\text { Low } \\
2400 / 1000000 \\
\text { High } \\
34900 / 1000000\end{array}$ & $\begin{array}{l}2280 / 1000000 \text { (2064 to } 2520) \\
33155 / 1000000 \text { (30014 to } 36645)\end{array}$ & RR 0.95 (0.86 to 1.05$)$ & 138302 (13 studies) & $\begin{array}{l}\oplus \oplus \oplus \oplus \\
\text { High }\end{array}$ \\
\hline $\begin{array}{l}\text { Mortality due to } \\
\text { all-cause diarrhoea } \\
\text { Follow-up: } 52-69 \text { weeks }\end{array}$ & $\begin{array}{l}\text { Low } \\
800 / 1000000 \\
\text { High } \\
3000 / 1000000\end{array}$ & $\begin{array}{l}760 / 1000000 \text { (552 to } 1048) \\
2850 / 1000000 \text { (2070 to } 3930)\end{array}$ & RR 0.95 (0.69 to 1.31$)$ & 132321 (4 studies) & $\begin{array}{l}\oplus \oplus \oplus \ominus \\
\text { Moderate† }\end{array}$ \\
\hline $\begin{array}{l}\text { Mortality due to LRTI } \\
\text { Follow-up: } 52-69 \text { weeks }\end{array}$ & $\begin{array}{l}\text { Low } \\
1200 / 1000000 \\
\text { High } \\
3000 / 1000000\end{array}$ & $\begin{array}{l}1032 / 1000000(768 \text { to } 1380) \\
2580 / 1000000(1920 \text { to } 3450)\end{array}$ & RR 0.86 (0.64 to 1.15$)$ & 132063 (3 studies) & $\begin{array}{l}\oplus \oplus \oplus \ominus \\
\text { Moderate† }\end{array}$ \\
\hline $\begin{array}{l}\text { Mortality due to malaria } \\
\text { Follow-up: } 46-69 \text { weeks }\end{array}$ & $\begin{array}{l}\text { Low } \\
7400 / 1000000 \\
\text { High } \\
14200 / 1000000\end{array}$ & $\begin{array}{l}6660 / 1000000 \text { (5698 to } 7844) \\
12780 / 1000000 \text { (10 } 934 \text { to } 15052)\end{array}$ & RR 0.90 (0.77 to 1.06$)$ & 42818 (2 studies) & $\begin{array}{l}\oplus \oplus \oplus \ominus \\
\text { Moderate† }\end{array}$ \\
\hline $\begin{array}{l}\text { Incidence of all-cause } \\
\text { diarrhoea } \\
\text { Follow-up: } 12-72 \text { weeks }\end{array}$ & $\begin{array}{l}\text { Low } \\
20000 / 1000000 \\
\text { High } \\
1770000 / 1000000\end{array}$ & $\begin{array}{l}17400 / 1000000 \text { (17000 to } 17800) \\
1539900 / 1000000(1504500 \text { to } 1575300)\end{array}$ & RR 0.87 (0.85 to 0.89$)$ & 15042 (35 studies) & $\begin{array}{l}\oplus \oplus \Theta \Theta \\
\text { Low } \ddagger \S\end{array}$ \\
\hline $\begin{array}{l}\text { Incidence of LRTI } \\
\text { Follow-up: } 12-52 \text { weeks }\end{array}$ & $\begin{array}{l}\text { Low } \\
30000 / 1000000 \\
\text { High } \\
370000 / 1000000\end{array}$ & $\begin{array}{l}30000 / 1000000 \text { (28 } 200 \text { to } 32100) \\
370000 / 1000000 \text { (347800 to } 395900)\end{array}$ & RR 1.00 (0.94 to 1.07$)$ & 9610 (12 studies) & $\begin{array}{l}\oplus \oplus \oplus \oplus \\
\text { High }\end{array}$ \\
\hline $\begin{array}{l}\text { Incidence of malaria } \\
\text { Follow-up: } 24-47 \text { weeks }\end{array}$ & $\begin{array}{l}\text { Low } \\
140000 / 1000000 \\
\text { High } \\
2950000 / 1000000\end{array}$ & $\begin{array}{l}147000 / 1000000(133000 \text { to } 161000) \\
3097500 / 1000000(2802500 \text { to } 3392500)\end{array}$ & RR 1.05 (0.95 to 1.15$)$ & 2407 (4 studies) & $\begin{array}{l}\oplus \oplus \oplus \Theta \\
\text { Moderateף }\end{array}$ \\
\hline $\begin{array}{l}\text { Height } \\
\text { Follow-up: } 10-60 \text { weeks } \\
\text { Participants with one } \\
\text { vomiting episode } \\
\text { Follow-up: } 24-52 \text { weeks }\end{array}$ & $\begin{array}{l}\text { The mean height in } \\
\text { the control groups was }-1 \mathrm{HAZ} \\
\text { Low } \\
17500 / 1000000 \\
\text { High } \\
300600 / 1000000\end{array}$ & $\begin{array}{l}\text { The mean height in the intervention } \\
\text { groups was } 0.1 \mathrm{HAZ} \text { better ( } 0 \text { to } 0.2 \text { better) } \\
22575 / 1000000 \text { (19 } 950 \text { to } 25550 \text { ) } \\
387774 / 1000000 \text { (342 } 684 \text { to } 438876 \text { ) }\end{array}$ & $\begin{array}{l}\text { SMD } 0.09(0.06 \text { to } 0.13) \\
\text { RR } 1.29(1.14 \text { to } 1.46)\end{array}$ & $\begin{array}{l}13669 \text { (51 studies) } \\
35192 \text { (4 studies) }\end{array}$ & $\begin{array}{l}\oplus \oplus \oplus \ominus \\
\text { Moderate }^{\star *} \\
\oplus \oplus \oplus \oplus \\
\text { High }\end{array}$ \\
\hline $\begin{array}{l}\text { GRADE working group g } \\
\text { High quality: further rese } \\
\text { Moderate quality: further } \\
\text { Low quality: further rese } \\
\text { Very low quality: we are } \\
\text { *The basis for the assum } \\
\text { comparison group and th } \\
+ \text { Few deaths were obser } \\
\mp 1^{2}=88 \% \text {. } \\
\S \text { Trim-and-fill analysis su } \\
\uparrow \|^{2}=44 \% \text {. } \\
\|\left._{\star \star *}\right|^{2}=86 \% \text {. }\end{array}$ & $\begin{array}{l}\text { of evidence. } \\
\text { is very unlikely to change our co } \\
\text { earch is likely to have an importar } \\
\text { is very likely to have an importan } \\
\text { uncertain about the estimate. } \\
\text { isk (eg, the median control group } \\
\text { lative effect of the intervention (a } \\
\text { overall. } \\
\text { sts that the effect may be overest }\end{array}$ & $\begin{array}{l}\text { ence in the estimate of effect. } \\
\text { ipact on our confidence in the estimate of effec } \\
\text { pact on our confidence in the estimate of effect } \\
\mathrm{k} \text { across studies) is provided in footnotes. The } \\
\text { ts } 95 \% \mathrm{Cl}) \text {. } \\
\text { ted due to publication bias. }\end{array}$ & $\begin{array}{l}\text { may change the estima } \\
\text { is likely to change the } \mathrm{e} \\
\text { sponding risk (and its } 95\end{array}$ & is based on the assumed & the \\
\hline
\end{tabular}




\section{Effects of zinc supplementation}

In addition to outcomes included in the summary of findings table (table 1), we analysed results for hospitalisation; prevalence of morbidities; additional measures of growth; as well as biological indicators of zinc, haemoglobin, iron and copper status (table 2). Subgroup analyses compared the effects of zinc supplementation with and without iron coadministration (table 3 , see online supplementary appendix 6).

Fourteen studies including 138302 participants were analysed for all-cause mortality, though other studies included no deaths in either group (figure 3), and there was high quality evidence of a small effect (risk ratio 0.95 (0.86 to 1.05$))$. There were similar effects for mortality due to diarrhoea (RR 0.95 (0.69 to 1.31)), mortality due to lower respiratory tract infection (LRTI; RR 0.86 (0.64 to 1.15$)$ ) and mortality due to malaria (RR 0.90 (0.77 to 1.06)), and the evidence for these outcomes was moderate quality.

In 25 studies including 15042 participants, there was low quality evidence of a $13 \%$ reduction in incidence of all-cause diarrhoea (figure 4; RR 0.87 (0.85 to 0.89)). Other measures of diarrhoea were consistent with no difference or with a small reduction in morbidity, including prevalence of all-cause diarrhoea, hospitalisation due to all-cause diarrhoea, incidence of severe diarrhoea,

Table 2 Zinc compared with no zinc (all outcomes)

\begin{tabular}{|c|c|c|c|c|}
\hline Outcomes & Trials & People & ES $(95 \% \mathrm{Cl})$, fixed effects & $\begin{array}{l}\text { Heterogeneity } \\
\left.\mathrm{I}^{2} ; \chi^{2} \text { ( } p \text { Value }\right)\end{array}$ \\
\hline \multicolumn{5}{|l|}{ Zinc vs no zinc } \\
\hline \multicolumn{5}{|l|}{ Mortality } \\
\hline All-cause & $13(16 \%)$ & 138302 (67\%) & Risk=0.95 (0.86 to 1.05$)$ & $0 \% ; 10.57(p=0.65)$ \\
\hline Due to diarrhoea & $4(5 \%)$ & $132321(64 \%)$ & Risk=0.95 (0.69 to 1.31$)$ & $0 \% ; 0.82(p=0.84)$ \\
\hline Due to LRTI & $3(4 \%)$ & $132063(64 \%)$ & Risk=0.86 (0.64 to 1.15$)$ & $0 \% ; 0.07(p=0.96)$ \\
\hline Due to malaria & $2(3 \%)$ & $42818(21 \%)$ & Risk=0.90 (0.77 to 1.06$)$ & $0 \% ; 0.01(p=0.94)$ \\
\hline \multicolumn{5}{|l|}{ Hospitalisation } \\
\hline All-cause & $7(9 \%)$ & $92872(45 \%)$ & Risk=1.04 (0.97 to 1.11$)$ & $44 \% ; 14.41(p=0.07)$ \\
\hline Due to diarrhoea & $4(5 \%)$ & 74039 (36\%) & Risk=1.03 (0.87 to 1.22$)$ & $42 \% ; 6.91(p=0.14)$ \\
\hline Due to LRTI & $3(4 \%)$ & 74743 (36\%) & Risk=1.10 (0.93 to 1.30$)$ & $0 \% ; 0.35(p=0.95)$ \\
\hline \multicolumn{5}{|l|}{ Diarrhoea } \\
\hline Incidence (all-cause) & 35 (44\%) & $15042(7 \%)$ & Risk=0.87 (0.85 to 0.89$)$ & $88 \% ; 295.56(p<0.00001)$ \\
\hline Prevalence (all-cause) & $13(16 \%)$ & $8519(4 \%)$ & Rate $=0.88(0.86$ to 0.90$)$ & $88 \% ; 118.88(p<0.00001)$ \\
\hline Incidence (severe) & $5(6 \%)$ & $4982(2 \%)$ & Risk=0.89 (0.84 to 0.95$)$ & $56 \% ; 13.54(p=0.04)$ \\
\hline Incidence (persistent) & $7(9 \%)$ & $6216(3 \%)$ & Risk=0.73 (0.62 to 0.85$)$ & $61 \% ; 20.47(p=0.009)$ \\
\hline Prevalence (persistent) & $1(1 \%)$ & $666(0 \%)$ & Rate $=0.70(0.64$ to 0.76$)$ & $91 \% ; 11.76(p=0.0006)$ \\
\hline \multicolumn{5}{|l|}{ LRTI } \\
\hline Incidence & $12(15 \%)$ & $9610(5 \%)$ & Risk=1.00 (0.94 to 1.07$)$ & $1 \% ; 17.16(p=0.44)$ \\
\hline Prevalence & $3(4 \%)$ & $1955(1 \%)$ & Rate $=1.20(1.10$ to 1.30$)$ & $97 \% ; 89.87(p<0.00001)$ \\
\hline \multicolumn{5}{|l|}{ Malaria } \\
\hline Incidence & $4(5 \%)$ & $2407(1 \%)$ & Risk=1.05 (0.95 to 1.15$)$ & $0 \% ; 2.04(p=0.84)$ \\
\hline Prevalence & $1(1 \%)$ & $661(0 \%)$ & Rate $=0.88(0.47$ to 1.64$)$ & Not applicable \\
\hline \multicolumn{5}{|l|}{ Growth } \\
\hline Height & $51(64 \%)$ & $13669(7 \%)$ & $S M D=0.09(0.06$ to 0.13$)$ & $86 \% ; 407.92(p<0.00001)$ \\
\hline Weight & $44(55 \%)$ & $12305(6 \%)$ & $S M D=0.10(0.07$ to 0.14$)$ & $76 \% ; 216.64(p<0.00001)$ \\
\hline Weight-to-height ratio & $24(30 \%)$ & 7901 (4\%) & $\mathrm{SMD}=0.05(0.01$ to 0.10$)$ & $20 \% ; 34.96(p=0.17)$ \\
\hline Prevalence of stunting & $6(8 \%)$ & $3838(2 \%)$ & Risk $=0.94$ (0.86 to 1.02$)$ & $59 \% ; 19.43(p=0.01)$ \\
\hline \multicolumn{5}{|l|}{ AEs } \\
\hline Participants with one AE & $2(3 \%)$ & $850(0 \%)$ & $S M D=1.13(1.00$ to 1.27$)$ & $0 \% ; 0.49(p=0.78)$ \\
\hline Study withdrawal & $6(8 \%)$ & $4263(2 \%)$ & Risk=1.75 (0.93 to 3.32) & $21 \% ; 5.07(p=0.28)$ \\
\hline Vomiting (incidence) & $5(6 \%)$ & 4095 (2\%) & Risk=1.68 (1.61 to 1.75$)$ & $85 \% ; 34.28(p<0.00001)$ \\
\hline Vomiting (prevalence) & $4(5 \%)$ & $35192(17 \%)$ & Rate $=1.29(1.14$ to 1.46$)$ & $37 \% ; 6.31(p=0.18)$ \\
\hline \multicolumn{5}{|l|}{ Biological indicators } \\
\hline Zn concentration & $46(58 \%)$ & $9810(5 \%)$ & $S M D=0.62(0.58$ to 0.67$)$ & $91 \% ; 582.45(p<0.00001)$ \\
\hline Zn deficiency (prevalence) & $15(19 \%)$ & $5434(3 \%)$ & Risk $=0.49(0.45$ to 0.53$)$ & $86 \% ; 144.77(p<0.00001)$ \\
\hline Haemoglobin concentration & 27 (34\%) & $6024(3 \%)$ & $S M D=-0.05(-0.10$ to 0.00$)$ & $45 \% ; 63.96(p=0.002)$ \\
\hline Anaemia (prevalence) & $13(16 \%)$ & $4287(2 \%)$ & Risk $=1.00(0.95$ to 1.06$)$ & $37 \% ; 28.52(p=0.05)$ \\
\hline Fe concentration & 19 (24\%) & $4474(2 \%)$ & $S M D=0.07(0.00$ to 0.13$)$ & $95 \% ; 480.50(p<0.00001)$ \\
\hline Fe deficiency (prevalence) & $10(13 \%)$ & $3149(2 \%)$ & Risk=0.99 (0.89 to 1.10$)$ & $15 \% ; 16.44(p=0.29)$ \\
\hline Cu concentration & $11(14 \%)$ & $3071(1 \%)$ & $S M D=-0.22(-0.29$ to 0.14$)$ & $68 \% ; 37.47(p=0.0002)$ \\
\hline Cu deficiency (prevalence) & $3(4 \%)$ & $1337(1 \%)$ & Risk=2.64 (1.28 to 5.42$)$ & $59 \% ; 4.94(p=0.08)$ \\
\hline
\end{tabular}


Table 3 Subgroup analyses

\begin{tabular}{|c|c|c|c|c|}
\hline $\begin{array}{l}\text { Subgroup } \\
\text { Mortality }\end{array}$ & $\begin{array}{l}\text { Trials } \\
13\end{array}$ & $\begin{array}{l}\text { People } \\
138302\end{array}$ & $\begin{array}{l}\text { Risk ratio }(95 \% \mathrm{Cl}) \text {, fixed } \\
0.95(0.86 \text { to } 1.05)\end{array}$ & $\begin{array}{l}I^{2} ; \chi^{2}(p \text { Value }) \\
0 \% ; 10.57(p=0.65)\end{array}$ \\
\hline \multicolumn{5}{|c|}{ Iron cosupplementation $\left(I^{2}=23 \% ; \chi^{2}=1.30, p=0.25\right)$} \\
\hline With iron & 4 & 99242 & $0.99(0.86$ to 1.15$)$ & $0 \% ; 0.76(p=0.86)$ \\
\hline Without iron & 11 & 64985 & $0.89(0.79$ to 1.00$)$ & $0 \% ; 9.99(p=0.44)$ \\
\hline \multicolumn{5}{|c|}{ Age $\left(I^{2}=59.8 \% ; \chi^{2}=2.48, p=0.11\right)$} \\
\hline 6 months to 1 year & 6 & 29879 & $1.06(0.88$ to 1.27$)$ & $0 \% ; 2.56(p=0.77)$ \\
\hline $1-5$ years & 8 & 125903 & $0.89(0.80$ to 0.99$)$ & $12 \% ; 10.28(p=0.33)$ \\
\hline \multicolumn{5}{|c|}{ Dose, $\mathrm{mg}\left(\mathrm{I}^{2}=0 \% ; \chi^{2}=2.64, \mathrm{p}=0.45\right)$} \\
\hline $0-5$ & 2 & 717 & $0.72(0.08$ to 6.47$)$ & $29 \% ; 1.41(p=0.23)$ \\
\hline $5-10$ & 1 & 274 & $3.04(0.32$ to 28.90$)$ & Not applicable \\
\hline $10-15$ & 11 & 152062 & $0.93(0.84$ to 1.02$)$ & $0 \% ; 8.16(p=0.61)$ \\
\hline 20 or more & 1 & 2464 & 0.14 (0.01 to 2.78$)$ & Not applicable \\
\hline \multicolumn{5}{|c|}{ Duration, months $\left(\mathrm{I}^{2}=0 \% ; \chi^{2}=1.20, \mathrm{p}=0.55\right)$} \\
\hline $0-6$ & 2 & 2817 & $0.59(0.07$ to 5.15$)$ & $47 \% ; 1.88 .(p=0.17)$. \\
\hline $6-12$ & 7 & 3898 & 0.68 (0.37 to 1.25$)$ & $4 \% ; 6.23(p=0.40)$ \\
\hline 12 or more & 6 & 148802 & $0.93(0.85$ to 1.03$)$ & $0 \% ; 2.91(p=0.71)$ \\
\hline \multicolumn{5}{|c|}{ Formulation $\left(I^{2}=0 \% ; \chi^{2}=0.54, p=0.91\right)$} \\
\hline Solution & 5 & 3639 & $0.99(0.25$ to 3.91$)$ & $15 \% ; 4.68(p=0.32)$ \\
\hline Pill/tablet & 8 & 149854 & 0.93 (0.85 to 1.02$)$ & $0 \% ; 6.99(p=0.43)$ \\
\hline Capsule & 1 & 306 & 0.51 (0.05 to 5.60$)$ & Not applicable \\
\hline Powder & 1 & 1718 & $0.71(0.27$ to 1.86$)$ & Not applicable \\
\hline Incidence of diarrhoea & 35 & 15042 & 0.87 (0.85 to 0.89$)$ & $88 \% ; 295.56(p<0.00001)$ \\
\hline \multicolumn{5}{|c|}{ Iron cosupplementation $\left(I^{2}=99 \% ; \chi^{2}=65.11, p<0.00001\right)$} \\
\hline With iron & 10 & 4299 & $1.00(0.96$ to 1.05$)$ & $76 \% ; 37.33(p<0.00001)$ \\
\hline Without iron & 22 & 11344 & $0.82(0.80$ to 0.84$)$ & $87 \% ; 196.27(p<0.00001)$ \\
\hline \multicolumn{5}{|c|}{ Age $\left(1^{2}=0 \% ; \chi^{2}=0.32, p=0.85\right)$} \\
\hline 6 months to 1 year & 10 & 5576 & $0.88(0.85$ to 0.90$)$ & $95 \% ; 252.46(p<0.00001)$ \\
\hline $1-5$ years & 15 & 8370 & $0.87(0.84$ to 0.90$)$ & $43 \% ; 31.48(p=0.03)$ \\
\hline $5-13$ years & 1 & 842 & 0.90 (0.81 to 0.98$)$ & Not applicable \\
\hline \multicolumn{5}{|c|}{ Dose, $\mathrm{mg}\left(\mathrm{I}^{2}=98 \% ; \chi^{2}=195.69, \mathrm{p}<0.00001\right)$} \\
\hline $0-5$ & 4 & 1784 & $0.95(0.89$ to 1.01$)$ & $73 \% ; 22.46(p=0.001)$ \\
\hline $5-10$ & 6 & 2630 & 0.73 (0.64 to 0.83$)$ & $67 \% ; 15.32(p=0.009)$ \\
\hline $10-15$ & 11 & 5452 & 0.96 (0.92 to 0.99$)$ & $69 \% ; 38.39(p=0.0001)$ \\
\hline $15-20$ & 2 & 477 & $0.61(0.58$ to 0.65$)$ & $0 \% ; 0.21(p<0.00001)$ \\
\hline 20 or more & 6 & 4931 & $0.90(0.87$ to 0.94$)$ & $75 \% ; 28.17(p<0.00001)$ \\
\hline \multicolumn{5}{|c|}{ Duration, months $\left(\mathrm{I}^{2}=0 \% ; \chi^{2}=1.15, \mathrm{p}=0.56\right)$} \\
\hline $0-6$ & 7 & 4190 & 0.89 (0.85 to 0.93$)$ & $57 \% ; 16.42(p=0.02)$ \\
\hline $6-12$ & 14 & 8971 & $0.86(0.84$ to 0.89$)$ & $93 \% ; 250.92(p<0.00001)$ \\
\hline 12 or more & 5 & 1881 & 0.88 (0.82 to 0.95$)$ & $73 \% ; 29.82(p=0.0002)$ \\
\hline \multicolumn{5}{|c|}{ Formulation $\left(I^{2}=94 \% ; \chi^{2}=51.34, p<0.00001\right)$} \\
\hline Solution & 19 & 10768 & $0.84(0.82$ to 0.86$)$ & $90 \% ; 236.48(p<0.00001)$ \\
\hline Pill/tablet & 3 & 1696 & $0.90(0.81$ to 0.99$)$ & $5 \% ; 3.15(p=0.37)$ \\
\hline Capsule & 1 & 612 & $0.78(0.60$ to 1.01$)$ & Not applicable \\
\hline Powder & 2 & 1861 & $1.04(0.98$ to 1.09$)$ & $0 \% ; 0.65(p=0.42)$ \\
\hline
\end{tabular}

prevalence of severe diarrhoea, incidence of persistent diarrhoea and prevalence of persistent diarrhoea.

In 12 trials (9610 participants), there was high-quality evidence of no effect on LRTI incidence (see online supplementary appendix 7; RR 1.00 (0.94 to 1.07)). One trial reported no LRTI in either group. ${ }^{20}$ Results for prevalence were consistent with no difference in respiratory morbidity.

Four trials (2407 participants) found moderate quality evidence that would be consistent with no effect or a harmful effect on malaria incidence (RR 1.04 (0.94,
1.14)). One study reported no significant effect on malaria prevalence.

Fifty studies reported height for 13669 participants (figure 5). There was moderate quality evidence of a very small but statistically significant increase in linear growth (SMD 0.09 (0.06 to 0.13)). Results for weight, weight-to-height ratio and prevalence of stunting were consistent with no difference or a small effect on growth.

Forty-six studies reported serum zinc for 9810 participants. There was evidence of a medium effect (SMD 


\begin{tabular}{|c|c|c|c|c|c|c|c|}
\hline Study or Subgroup & log[Risk Ratio] & SE & $\begin{array}{c}\text { Zinc } \\
\text { Total }\end{array}$ & $\begin{array}{l}\text { No Zinc } \\
\text { Total }\end{array}$ & Weight & $\begin{array}{l}\text { Risk Ratio } \\
\text { IV, Fixed, } 95 \% \mathrm{Cl}\end{array}$ & $\begin{array}{c}\text { Risk Ratio } \\
\text { IV, Fixed, } 95 \% \mathrm{CI}\end{array}$ \\
\hline \multicolumn{8}{|c|}{3.1 .16 months to $<1$ year } \\
\hline Baqui 2003 & 1.07361099 & 1.62916074 & 161 & 157 & $0.1 \%$ & $2.93[0.12,71.29]$ & \\
\hline Chang 2010 & -1.59447504 & 1.54597037 & 198 & 201 & $0.1 \%$ & $0.20[0.01,4.20]$ & $\longleftarrow$ \\
\hline Lind 2003 & 1.60943791 & 1.54541389 & 170 & 170 & $0.1 \%$ & $5.00[0.24,103.38]$ & $\leftarrow$ \\
\hline Chhagan 2009 & 0.02643326 & 0.99114872 & 112 & 115 & $0.2 \%$ & $1.03[0.15,7.16]$ & \\
\hline Tielsch $2006(2)$ & 0.01267064 & 0.31113591 & 1017 & 966 & $2.4 \%$ & $1.01[0.55,1.86]$ & \\
\hline $\begin{array}{l}\text { Sazawal } 2006 \\
\text { Subtotal }(95 \% \mathrm{CI})\end{array}$ & 0.05826891 & 0.10048763 & $\begin{array}{l}13294 \\
14952\end{array}$ & $\begin{array}{l}13318 \\
14927\end{array}$ & $\begin{array}{l}23.0 \% \\
25.9 \%\end{array}$ & $\begin{array}{l}1.06[0.87,1.29] \\
1.06[0.88,1.27]\end{array}$ & \\
\hline \multicolumn{8}{|c|}{$\begin{array}{l}\text { Heterogeneity: } \mathrm{Chi}^{2}=2.56, \mathrm{df}=5(\mathrm{P}=0.77) ; \mathrm{I}^{2}=0 \% \\
\text { Test for overall effect: } Z=0.60(P=0.55)\end{array}$} \\
\hline \multicolumn{8}{|l|}{3.1 .21 to $<5$ years } \\
\hline Larson 2010 & 1.10424611 & 1.6295395 & 176 & 177 & $0.1 \%$ & $3.02[0.12,73.56]$ & \\
\hline Penny 2004 & -1.58534036 & 1.54139551 & 81 & 83 & $0.1 \%$ & $0.20[0.01,4.20]$ & \\
\hline Bhandari 2002 & -1.93942189 & 1.51132135 & 1228 & 1236 & $0.1 \%$ & $0.14[0.01,2.78]$ & \\
\hline Veenemans 2011 (2) & -0.6670019 & 1.2193957 & 151 & 155 & $0.2 \%$ & $0.51[0.05,5.60]$ & \\
\hline Shankar 2000 & 1.11321109 & 1.14836145 & 136 & 138 & $0.2 \%$ & $3.04[0.32,28.90]$ & \\
\hline Muller 2001 & -0.86670956 & 0.52677681 & 341 & 344 & $0.8 \%$ & $0.42[0.15,1.18]$ & \\
\hline Tielsch 2006 & -0.22948879 & 0.12870764 & 8731 & 8484 & $14.0 \%$ & $0.79[0.62,1.02]$ & \\
\hline Sazawal 2006 (2) & -0.03756725 & 0.11932628 & 8120 & 7950 & $16.3 \%$ & $0.96[0.76,1.22]$ & \\
\hline Bhandari 2007 & 0.04493755 & 0.11212408 & 36293 & 36145 & $18.4 \%$ & $1.05[0.84,1.30]$ & \\
\hline $\begin{array}{l}\text { Sazawal } 2006 \\
\text { Subtotal }(95 \% \mathrm{CI})\end{array}$ & -0.19845094 & 0.09838509 & $\begin{array}{r}7980 \\
63237\end{array}$ & $\begin{array}{r}7954 \\
62666\end{array}$ & $\begin{array}{l}24.0 \% \\
74.1 \%\end{array}$ & $\begin{array}{r}0.82[0.68,0.99] \\
0.89[0.80,0.99]\end{array}$ & \\
\hline \multicolumn{8}{|c|}{$\begin{array}{l}\text { Heterogeneity: } \mathrm{Chi}^{2}=10.28, \mathrm{df}=9(P=0.33) ; \mathrm{I}^{2}=12 \% \\
\text { Test for overall effect: } Z=2.08(P=0.04)\end{array}$} \\
\hline Total $(95 \% \mathrm{CI})$ & & & 78189 & 77593 & $100.0 \%$ & $0.93[0.85,1.02]$ & \\
\hline \multicolumn{7}{|c|}{$\begin{array}{l}\text { Heterogeneity: } \mathrm{Chi}^{2}=15.32, \mathrm{df}=15(\mathrm{P}=0.43) ; \mathrm{I}^{2}=2 \% \\
\text { Test for overall effect: } \mathrm{Z}=1.49(\mathrm{P}=0.14) \\
\text { Test for subgroup differences: } \mathrm{Chi}^{2}=2.48, \mathrm{df}=1(\mathrm{P}=0.11), \mathrm{I}^{2}\end{array}$} & \begin{tabular}{c|c}
1 & 1.50 .7 \\
Favours Zinc Favours
\end{tabular} \\
\hline
\end{tabular}

Figure 3 All-cause mortality by age.

$0.62(0.58$ to 0.67$))$ on zinc concentration. Results consistently favoured zinc rather than no-intervention, but they were extremely inconsistent in magnitude, possibly due to differences in participants and settings $\left(\chi^{2}=582.45, \mathrm{df}=47 \quad(\mathrm{p}<0.00001) ; \mathrm{I}^{2}=91 \%\right)$. Eleven studies reported serum copper for 3071 participants (1\% of participants in this review). There was very low-quality evidence of a small reduction in copper (SMD -0.22 $(-0.29$ to 0.14$))$; as above, the results were inconsistent $\left(\chi^{2}=37.47, \mathrm{df}=10 \quad(\mathrm{p}<0.0002) ; \mathrm{I}^{2}=68 \%\right)$. There was no evidence of an effect on haemoglobin, prevalence of anaemia or iron status.

In five trials (35 192participants), there was highquality evidence of increased vomiting (RR 1.29 (1.14 to 1.46)). Two trials reported no adverse events in either group (ie, supplemented or non-supplemented). ${ }^{21} 22$ Results for study withdrawal, participants with one or more side effects and number of vomiting episodes indicate some short-term side effects; there was no evidence of serious adverse events.

\section{Effects of zinc plus iron compared with zinc alone}

Effects on mortality were not significantly different between subgroups with and without iron $\left(\chi^{2}=1.30\right.$, $\mathrm{p}=0.25)$; however, there was no mortality effect in groups receiving iron (RR 0.99 (0.86 to 1.15)) while the effect for groups that did not receive iron was nearly significant (RR 0.89 (0.79 to 1.00)). Effects on the incidence of diarrhoea differed between groups (figure 4; $\chi^{2}=65.11, \mathrm{p}<0.00001$ ), with no benefit for the group that received iron (RR $1.00(0.96$ to 1.05$)$ ) and a significant benefit for the group that did not receive iron (RR 0.82 $(0.80$ to 0.84$))$. There were significant effects with and without iron cosupplementation on zinc status; these were greater in studies without iron for serum zinc $\left(\chi^{2}=27.07, \mathrm{p}<0.00001\right)$ and prevalence of zinc deficiency $\left(\chi^{2}=34.27, \quad \mathrm{p}<0.00001\right)$. There were also differences between these groups of studies for serum ferritin and serum copper; zinc had no effect in studies with iron cointervention, but zinc without iron cointervention reduced ferritin and copper. Overall effects on growth were small; there was a significant difference between subgroups for height but not weight, and the difference for weight-to-height ratio favoured the group that received iron (ie, the opposite of the other results). There were no significant effects in either subgroup for LRTIs, serum haemoglobin, prevalence of anaemia or prevalence of iron deficiency.

Several trials compared zinc coadministered with iron versus zinc given alone (see online supplementary appendix 6). One trial reported no significant difference in all-cause mortality (323 participants; RR 0.33 (0.01 to 8.39)). In five trials (1530 participants), effects on incidence of all-cause diarrhoea favoured zinc alone (RR 1.10 (1.03 to 1.18)). In one trial (399 participants), effects on prevalence of all-cause diarrhoea favoured zinc with iron, but this was not significant (RR 0.90 (0.79 to 1.06$))$. Five trials (1329 participants) reported no difference in height (SMD $0.06(-0.04$ to 0.16$)$ ). Similarly, there was low-quality evidence and mixed results for other outcomes (table 4).

\section{Additional subgroup analyses}

Studies in high-income countries did not evaluate most outcomes, so we were unable to explore differences in effect by national income. Effects on weight and 


\begin{tabular}{|c|c|c|c|c|c|c|c|c|}
\hline Study or Subgroup & log[Risk Ratio] & SE & $\begin{array}{l}\text { Zinc N } \\
\text { Total }\end{array}$ & $\begin{array}{l}\text { No Zinc } \\
\text { Total }\end{array}$ & Weight & $\begin{array}{c}\text { Risk Ratio } \\
\text { IV, Fixed, } 95 \% \mathrm{CI}\end{array}$ & $\begin{array}{r}\text { Risk } \\
\text { IV, Fixed }\end{array}$ & $\begin{array}{l}\text { k Ratio } \\
\text { d, } 95 \% \mathrm{CI}\end{array}$ \\
\hline \multicolumn{9}{|c|}{ 3.9.1 Iron co-intervention } \\
\hline Meeks Gardner 2005 & -4.48367263 & 1.42163731 & 55 & 59 & $0.0 \%$ & $0.01[0.00,0.18]$ & 4 & \\
\hline Cole 2012 & -0.26503449 & 0.37388896 & 75 & 68 & $0.1 \%$ & $0.77[0.37,1.60]$ & & \\
\hline Alarcon 2004 & -0.33963305 & 0.30181636 & 112 & 111 & $0.1 \%$ & $0.71[0.39,1.29]$ & & \\
\hline Rosado 1997 (2) & -0.52044108 & 0.18680745 & 55 & 54 & $0.4 \%$ & $0.59[0.41,0.86]$ & & \\
\hline Veenemans 2011 (2) & -0.27010424 & 0.17803183 & 151 & 155 & $0.4 \%$ & $0.76[0.54,1.08]$ & & \\
\hline Lind 2003 (2) & -0.07145896 & 0.09311961 & 170 & 170 & $1.4 \%$ & $0.93[0.78,1.12]$ & & \\
\hline Chang 2010 (2) & -0.25350318 & 0.0794688 & 400 & 201 & $2.0 \%$ & $0.78[0.66,0.91]$ & & \\
\hline Richard 2006 (2) & 0.03619935 & 0.06581383 & 210 & 208 & $2.9 \%$ & $1.04[0.91,1.18]$ & & \\
\hline Baqui 2003 (2) & 0.08849308 & 0.05540904 & 162 & 165 & $4.0 \%$ & $1.09[0.98,1.22]$ & & \\
\hline $\begin{array}{l}\text { Soofi } 2013 \\
\text { Subtotal }(95 \% \mathrm{CI})\end{array}$ & 0.03774033 & 0.02689562 & $\begin{array}{r}853 \\
2243\end{array}$ & $\begin{array}{r}865 \\
2056\end{array}$ & $\begin{array}{l}17.1 \% \\
28.4 \%\end{array}$ & $\begin{array}{l}1.04[0.99,1.09] \\
1.00[0.96,1.05]\end{array}$ & & \\
\hline \multicolumn{9}{|c|}{$\begin{array}{l}\text { Heterogeneity: } \text { Chi }^{2}=37.33, \mathrm{df}=9(P<0.0001): \mathrm{I}^{2}=76 \% \\
\text { Test for overall effect: } Z=0.20(P=0.84)\end{array}$} \\
\hline \multicolumn{9}{|c|}{ 3.9.2 No iron co-intervention } \\
\hline Chang 2010 (2) & -0.27537422 & 0.36843806 & 201 & 201 & $0.1 \%$ & $0.76[0.37,1.56]$ & & \\
\hline Chang 2010 & -0.58978851 & 0.33149677 & 198 & 201 & $0.1 \%$ & $0.55[0.29,1.06]$ & & \\
\hline Han 2002 & -0.75662302 & 0.28075433 & 33 & 22 & $0.2 \%$ & $0.47[0.27,0.81]$ & & \\
\hline Han $2002(2)$ & -0.17923468 & 0.27919905 & 24 & 26 & $0.2 \%$ & $0.84[0.48,1.44]$ & & \\
\hline Meeks Gardner 1998 & 0.00421645 & 0.25610818 & 31 & 30 & $0.2 \%$ & $1.00[0.61,1.66]$ & & \\
\hline Umeta 2000 & -0.78170058 & 0.23234928 & 100 & 100 & $0.2 \%$ & $0.46[0.29,0.72]$ & & \\
\hline Cupta 2003 & -0.89381788 & 0.22473329 & 186 & 94 & $0.2 \%$ & $0.41[0.26,0.64]$ & & \\
\hline Rosado 1997 & -0.40188729 & 0.20280294 & 54 & 56 & $0.3 \%$ & $0.67[0.45,1.00]$ & & \\
\hline Veenemans 2011 & -0.22342699 & 0.19743482 & 153 & 153 & $0.3 \%$ & $0.80[0.54,1.18]$ & & \\
\hline Penny 2004 & -0.11778304 & 0.10486269 & 80 & 79 & $1.1 \%$ & $0.89[0.72,1.09]$ & & \\
\hline Ruel 1997 & -0.25131443 & 0.10417938 & 55 & 53 & $1.1 \%$ & $0.78[0.63,0.95]$ & & \\
\hline Gupta 2007 & -0.14660347 & 0.097381 & 854 & 858 & $1.3 \%$ & $0.86[0.71,1.05]$ & & \\
\hline Wuehler 2008 & -0.30010459 & 0.09601332 & 353 & 116 & $1.3 \%$ & $0.74[0.61,0.89]$ & - & \\
\hline Lind 2003 & 0.06899287 & 0.09065627 & 170 & 170 & $1.5 \%$ & $1.07[0.90,1.28]$ & & \\
\hline Larson 2010 & -0.23381808 & 0.08123116 & 176 & 177 & $1.9 \%$ & $0.79[0.68,0.93]$ & $\longrightarrow$ & \\
\hline Muller 2001 & -0.14077255 & 0.07595902 & 342 & 344 & $2.1 \%$ & $0.87[0.75,1.01]$ & & \\
\hline Chhagan 2009 & -0.04913269 & 0.07335707 & 104 & 105 & $2.3 \%$ & $0.95[0.82,1.10]$ & & \\
\hline Richard 2006 & -0.28106642 & 0.07078211 & 209 & 215 & $2.5 \%$ & $0.75[0.66,0.87]$ & - & \\
\hline Long 2006 & 0.12218449 & 0.07061765 & 181 & 183 & $2.5 \%$ & $1.13[0.98,1.30]$ & & \\
\hline Long 2006 (2) & -0.26514098 & 0.06888881 & 192 & 180 & $2.6 \%$ & $0.77[0.67,0.88]$ & - & \\
\hline Rahman 2001 (2) & -0.05001042 & 0.06042171 & 175 & 160 & $3.4 \%$ & $0.95[0.84,1.07]$ & & \\
\hline Rahman 2001 & -0.13353139 & 0.0579042 & 170 & 161 & $3.7 \%$ & $0.88[0.78,0.98]$ & 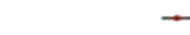 & \\
\hline Baqui 2003 & -0.02439145 & 0.05739701 & 161 & 157 & $3.8 \%$ & $0.98[0.87,1.09]$ & & \\
\hline Sazawal 1996 & -0.08461665 & 0.04515217 & 286 & 293 & $6.1 \%$ & $0.92[0.84,1.00]$ & & \\
\hline Malik 2013 & -0.48917615 & 0.02918358 & 134 & 124 & $14.5 \%$ & $0.61[0.58,0.65]$ & - & \\
\hline $\begin{array}{l}\text { Bhandari } 2002 \\
\text { Subtotal }(95 \% \mathrm{Cl})\end{array}$ & -0.10583655 & 0.02613411 & $\begin{array}{l}1228 \\
\mathbf{5 8 5 0}\end{array}$ & $\begin{array}{l}1236 \\
5494\end{array}$ & $\begin{array}{l}18.1 \% \\
71.6 \%\end{array}$ & $\begin{array}{c}0.90[0.85,0.95] \\
0.82[0.80,0.84]\end{array}$ & 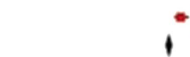 & \\
\hline \multicolumn{9}{|c|}{$\begin{array}{l}\text { Heterogeneity: } \mathrm{Ch}^{2}=196.27 . \mathrm{df}=25(\mathrm{P}<0.00001): \mathrm{I}^{2}=87 \% \\
\text { Test for overall effect: } Z=14.83(\mathrm{P}<0.00001)\end{array}$} \\
\hline \multirow{2}{*}{\multicolumn{4}{|c|}{$\begin{array}{l}\text { Total }(95 \% \mathrm{Cl}) \\
\text { Heterogeneity: } \mathrm{Chi}^{2}=298.70, \mathrm{df}=35(\mathrm{P}<0.00001): \mathrm{I}^{2}=88 \% \\
\text { Test for overall effect: } \mathrm{Z}=12.45(\mathrm{P}<0.00001)\end{array}$}} & 7550 & $100.0 \%$ & $0.87[0.85,0.89]$ & 1 & \\
\hline & & & & & & & $\begin{array}{l}1 \\
0.50 .7 \\
\text { Favours Zinc }\end{array}$ & \\
\hline
\end{tabular}

Figure 4 Incidence of all-cause diarrhoea with and without iron cosupplementation.

weight-to-height ratio were not statistically different, and there was no evidence of consistent differences in biological outcomes (see online supplementary appendix 6).

Most studies included stunted and non-stunted children, and it was not possible to compare effects between studies for most outcomes. Differences between groups were not significant for growth, but these would be consistent with larger effects in studies of stunted children.

Age was not significantly associated with effects on mortality or incidence diarrhoea, but results would be consistent with greater benefits in children over 1 year of age (figure 3). Effects on weight were greatest in studies of older children, and there was a similar pattern for height, though the largest study of children over 5 years of age included only 804 participants. The effect of supplementation on zinc deficiency was greater in studies of older children, as was the negative effect on copper. There was no evidence of consistent differences in other biological outcomes.

Dose was not significantly associated with effects on mortality, incidence of LRTI, haemoglobin or weight-to-height ratio. The pattern of results was inconsistent for incidence and prevalence of diarrhoea, height, weight and plasma ferritin (see online supplementary appendix 6). Subgroups were significantly different for serum zinc, prevalence of zinc deficiency, prevalence of iron deficiency and plasma copper; only these results are consistent with a dose-response relationship.

Duration of supplementation was not significantly associated with effects on mortality, incidence of diarrhoea, incidence of LRTI, weight-to-height ratio or prevalence of iron deficiency (see online supplementary appendix 6). There was a significant difference for 


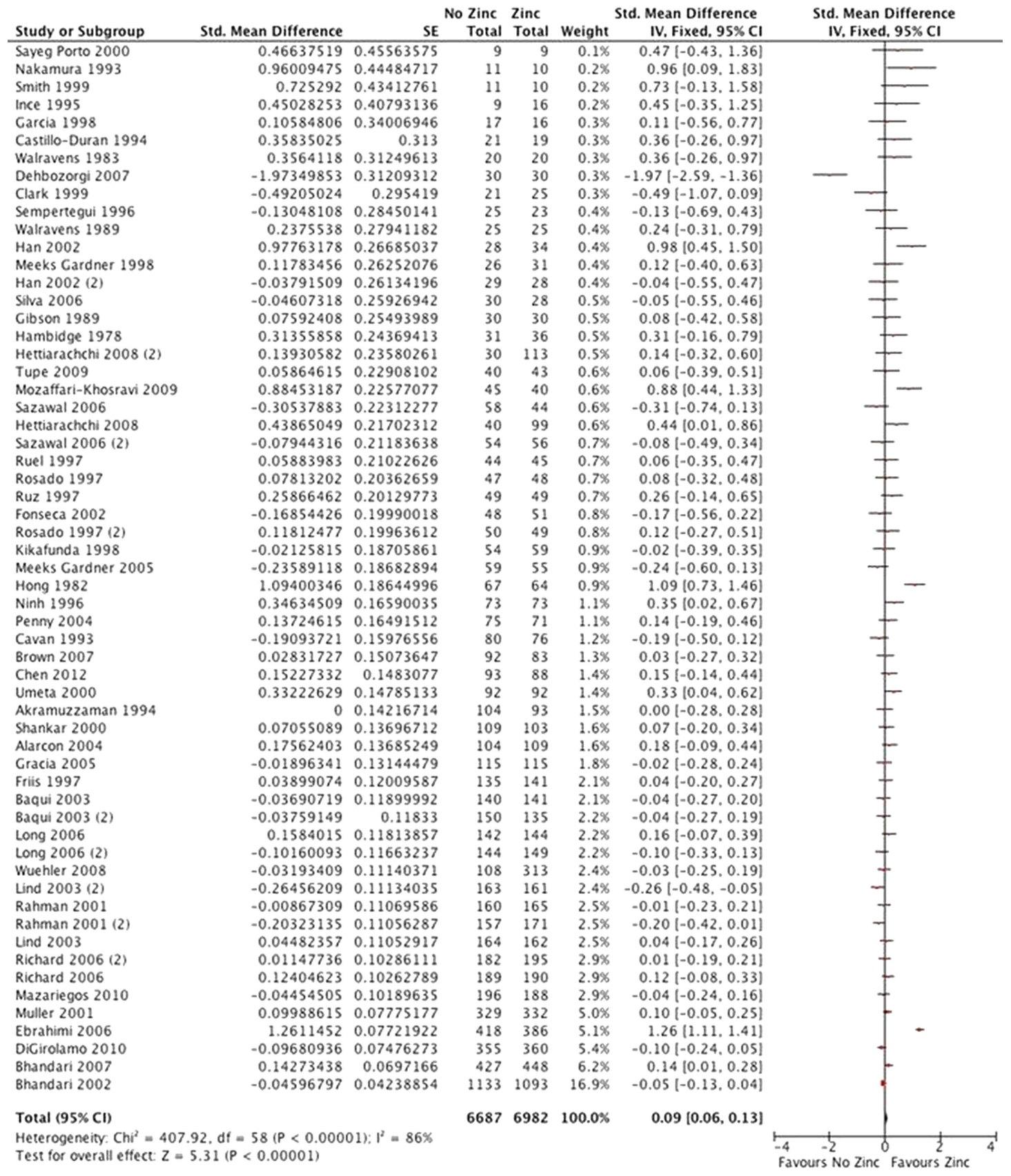

prevalence of diarrhoea, but the magnitude of this difference may not be important. Studies of longer supplementation were associated with greater effects on height; the pattern of results was not consistent for weight. By contrast, the largest benefits for biological markers (serum zinc and prevalence of zinc deficiency) were reported in the shortest studies.

Formulation was associated with differences among subgroups, though few studies included capsules or powder. When comparing solution and tablets, differences were not significant for mortality, incidence and prevalence of diarrhoea; incidence of LRTI; blood haemoglobin; prevalence of anaemia or prevalence of iron deficiency. There were significant differences in the effects of serum ferritin and serum copper, but only three studies of each outcome used tablets, and they were highly heterogeneous. The effects on height, weight and serum zinc were greater in studies using solution compared with tablet, but all effects were small (see online supplementary appendix 6 ).

\section{Reporting bias}

For outcomes included in the summary of findings table with 10 or more studies, we also conducted a trim-and-fill analysis to investigate reporting bias (see online supplementary appendix 8). ${ }^{23}$ There was some evidence of small study bias-studies were trimmed for all-cause mortality (1 trimmed) and incidence of 
Table 4 Zinc with iron compared with zinc alone (all outcomes)

\begin{tabular}{|c|c|c|c|c|}
\hline Outcomes & Trials & People & ES $(95 \% \mathrm{Cl})$, fixed effects & $\begin{array}{l}\text { Heterogeneity } \\
\mathrm{I}^{2} ; \chi^{2} \text { (p Value) }\end{array}$ \\
\hline $\begin{array}{l}\text { All-cause mortality } \\
\text { Hospitalisation }\end{array}$ & $1(13 \%)$ & $323(17 \%)$ & Risk=0.33 (0.01 to 8.31) & Not applicable \\
\hline All-cause & $1(13 \%)$ & $399(21 \%)$ & Risk=0.92 (0.45 to 1.89$)$ & Not applicable \\
\hline Due to diarrhoea & $1(13 \%)$ & $399(21 \%)$ & Risk=0.99 (0.25 to 3.88$)$ & Not applicable \\
\hline \multicolumn{5}{|l|}{ Diarrhoea } \\
\hline Incidence (all-cause) & $5(63 \%)$ & $1530(81 \%)$ & Risk=1.10 (1.03 to 1.18$)$ & $76 \% ; 16.92(p=0.002)$ \\
\hline Prevalence (all-cause) & $1(13 \%)$ & 399 (21\%) & Rate $=0.90(0.79$ to 1.06$)$ & Not applicable \\
\hline Incidence (severe) & $1(13 \%)$ & $323(17 \%)$ & Rate $=0.78$ (0.59 to 1.04$)$ & Not applicable \\
\hline \multicolumn{5}{|l|}{ Lower respiratory tract infection } \\
\hline Incidence & $3(38 \%)$ & $1065(56 \%)$ & Risk=0.93 (0.83 to 1.04$)$ & $21 \% ; 2.52(p=0.28)$ \\
\hline \multicolumn{5}{|l|}{ Malaria } \\
\hline Incidence & $1(13 \%)$ & $410(22 \%)$ & Rate $=0.86(0.59$ to 1.24$)$ & Not applicable \\
\hline \multicolumn{5}{|l|}{ Growth } \\
\hline Height & $5(63 \%)$ & $1517(80 \%)$ & $S M D=0.06(-0.04$ to 0.16$)$ & $0 \% ; 3.54(p=0.47)$ \\
\hline Weight & $4(50 \%)$ & $910(48 \%)$ & $\mathrm{SMD}=0.12(-0.01$ to 0.25$)$ & $0 \% ; 2.29(p=0.51)$ \\
\hline Weight-to-height ratio & $4(50 \%)$ & $514(27 \%)$ & $\mathrm{SMD}=-0.06(-0.07$ to 0.19$)$ & $0 \% ; 1.36(p=0.71)$ \\
\hline Prevalence of stunting & $2(25 \%)$ & $462(24 \%)$ & Risk $=0.92(0.85$ to 0.99$)$ & $45 \% ; 1.82(p=0.18)$ \\
\hline \multicolumn{5}{|l|}{ Adverse events } \\
\hline Study withdrawal & $2(25 \%)$ & $557(29 \%)$ & Risk=1.41 (0.91 to 2.18$)$ & $0 \% ; 0.08(p=0.78)$ \\
\hline \multicolumn{5}{|l|}{ Biological indicators } \\
\hline Zn concentration & $8(100 \%)$ & $1337(70 \%)$ & $S M D=0.16(0.05$ to 0.27$)$ & $61 \% ; 17.84(p=0.01)$ \\
\hline Zn deficiency (prevalence) & $3(38 \%)$ & $350(18 \%)$ & Risk $=1.42(0.75$ to 2.68$)$ & $5 \% ; 2.10(p=0.35)$ \\
\hline Haemoglobin concentration & $8(100 \%)$ & $1341(71 \%)$ & $S M D=-0.23(-0.34$ to -0.12$)$ & $79 \% ; 33.53(p<0.0001)$ \\
\hline Anaemia (prevalence) & $3(38 \%)$ & $482(25 \%)$ & Risk $=0.78$ (0.67 to 0.92$)$ & $0 \% ; 1.25(p=0.54)$ \\
\hline Fe concentration & $6(75 \%)$ & $945(50 \%)$ & $\mathrm{SMD}=-1.79(-1.99$ to -1.56$)$ & $99 \% ; 927.92(p<0.00001)$ \\
\hline Fe deficiency (prevalence) & $2(25 \%)$ & $248(13 \%)$ & Risk $=0.12(0.04$ to 0.32$)$ & $87 \% ; 8.00(p=0.005)$ \\
\hline Cu concentration & $2(25 \%)$ & $353(19 \%)$ & $S M D=-0.06(-0.27$ to 0.15$)$ & $0 \% ; 0.11(p=0.74)$ \\
\hline
\end{tabular}

all-cause diarrhoea (13 trimmed; figure 6). None were trimmed for incidence of LRTI; nor were any trimmed for height. The adjusted effect for mortality was not importantly different from the observed effect, but the observed effect for diarrhoea (RR 0.87 (0.85 to 0.89)) was larger than the adjusted value ( RR 0.95 (0.93 to 0.97)).

\section{DISCUSSION}

Consistent with previous reviews, this review finds highquality evidence from several large, well-conducted trials. ${ }^{5} 710$ We believe that these results suggest zinc supplementation is probably associated with a small reduction in all-cause mortality for children at risk of deficiency. In interpreting these results, we considered that the results of this meta-analysis are drawn from 13 trials including almost 140000 participants. The results of those studies are statistically consistent, the overall CIs are relatively small and the balance of probability favours zinc supplementation rather than placebo. Small reductions in cause-specific mortality were consistent with effects on illness and cause-specific mortality, and the results were biologically plausible. Benefits in any specific area may be related to the level of deficiency; countries with very high levels of deficiency could expect the largest reductions in mortality as a result of supplementation. ${ }^{24}$ This review also suggests that benefits may not be restricted to young children; there is some evidence of benefits on secondary outcomes in trials including children over 5 years of age, but there is a lack of evidence about the effects on mortality in this group.

Results for secondary outcomes suggest modest benefits. The main results for diarrhoea morbidity were consistent with previous reviews, ${ }^{45} 7{ }^{10}$ but an asymmetrical funnel plot was indicative of small-study bias. After adjustment, the effect for diarrhoea was halved, and the reduced estimate was consistent with other critical outcomes in this review. Previous reviews have suggested beneficial effects on respiratory infections ${ }^{45-12}$ and malaria, ${ }^{10}$ which this review does not confirm, and also reported variable effects on growth ${ }^{5}{ }^{6} 8$; this review suggests that preventive zinc supplementation alone is unlikely to have large effects on linear growth and morbidity. Supplementation is associated with increased risk of vomiting, but there is no evidence of lasting adverse effects.

Critical outcomes included data for 2407-138 302 participants, so further placebo-controlled trials of 


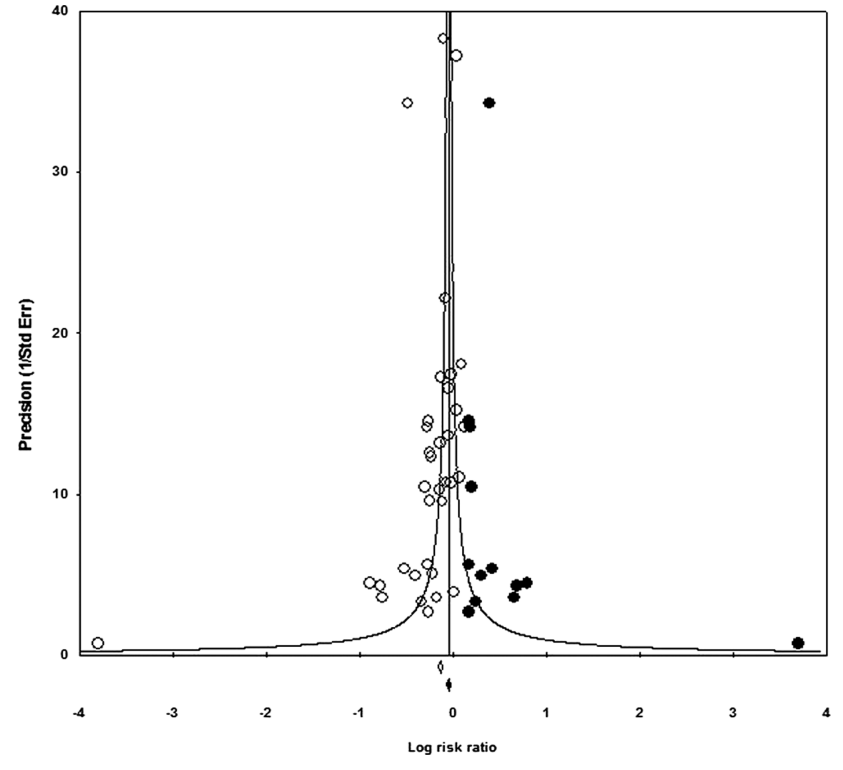

Figure 6 Incidence of diarrhoea funnel plot (trim-and-fill analysis).

preventive zinc supplementation for young children may not be necessary. However, subgroup analyses did not identify an optimal supplementation strategy (ie, dose, formulation and frequency), and large trials comparing active interventions could inform clinical guidelines. Subgroup analyses identify some sources of observed heterogeneity; however, subgroups that were statistically different included a large amount of residual heterogeneity, which is reflected in our judgements about the quality of the evidence (table 1). Analyses of group-level data are of limited value for identifying moderators, particularly in analyses dominated by a few large studies. Further analyses of individual patient data would be more conclusive.

Effects on biological indicators were inconsistent across studies, but large effects on these measures were not always reflected in clinical outcomes. Supplementation may increase serum zinc, but the magnitude of the effect appears to differ across populations and interventions. Effects on other micronutrients, including iron and copper, are uncertain. Researchers have suggested that iron supplementation may interfere with the absorption of zinc and, conversely, that zinc may interfere with iron and copper absorption ${ }^{25}{ }^{26}$; however, the relationships between these biomarkers and clinical outcomes (ie, mortality and morbidities) have not been established.

Subgroup analyses comparing zinc with and without iron did not resolve uncertainty about the effect of cosupplementation. Only four studies with iron cosupplementation reported mortality outcomes, and evidence of outcome reporting bias for diarrhoea incidence leads to cautious interpretation of differences in this outcome. There was no evidence that larger doses or increased duration was associated with increased iron deficiency, but these comparisons are observational and could be affected by uncontrolled covariates.

Direct comparisons within trials provide the only experimental evidence about the effects of cosupplementation with iron. For rare events like mortality, effects of zinc and iron can only be detected in large studies, so studies of interaction effects will need to be very large to detect real differences. Future studies are needed to identify the main effects and to explore how administration (ie, separate or combined) affects uptake and costs.

Dietary intake and supplementation have reduced micronutrient deficiencies in Asia, but micronutrient deficiencies remain common. ${ }^{3} 27$ The prevalence of micronutrient deficiencies is declining in Africa, but the absolute number of deficient children is increasing. ${ }^{3}$ This review suggests that the overall benefits of preventive zinc supplementation outweigh potential harms in areas with a high risk of zinc deficiency. Further research is needed to determine if these benefits extend to children over 5 years of age. Current estimates suggest that delivering 10 evidence-based nutrition-specific interventions, including preventive zinc supplements, could reduce global mortality in children under 5 years of age by $15 \% .^{28}$ To that end, research is needed to identify the most effective strategies for delivering zinc supplements to populations in need. ${ }^{29}$

\section{Author affiliations}

${ }^{1}$ Department of Epidemiology, Center for Clinical Trials and Evidence Synthesis, Johns Hopkins Bloomberg School of Public Health, Baltimore, Maryland, USA

${ }^{2}$ Department of Pediatrics, SUNY Upstate Medical University, Syracuse, New York, USA

${ }^{3}$ Harvard Medical School, Boston, Massachusetts, USA

${ }^{4}$ Albert Einstein Medical Center, Philadelphia, Pennsylvania, USA

${ }^{5}$ SickKids Center for Global Child Health, Toronto, Canada

${ }^{6}$ Center of Excellence in Women and Child Health, The Aga Khan University, Karachi, Pakistan

Acknowledgements The authors would like to thank the Cochrane Developmental Psychosocial and Learning Problems Group, particularly the following: Margaret Anderson helped develop and conduct the searches; Laura MacDonald, Joanne Wilson and Geraldine Macdonald assisted with the preparation of the protocol and review; Geraldine Macdonald provided detailed comments on the protocol and completed the review. The Cochrane Methods Group provided statistical advice and assistance. Chris Champion extracted one study in Portuguese. Evelyn S Chan, Xin Hui Chan, Jai Das and Aneil Jaswal extracted the study data.

Contributors All authors contributed to the background. EM-W and JJ were responsible for the methods. JJ executed the first literature search, and EM-W and $\mathrm{Al}$ executed the update. JJ, EM-W, Al and EC reviewed the citations for inclusion. JJ, EM-W, Al, SD, Evelyn S Chan, Xin Hui Chan, Jai Das and Aneil Jaswal extracted the study data. JJ and EM-W entered the outcome data into RevMan and analysed the data. EM-W, JJ and Al wrote the results and discussion. EM-W and Al drafted the summary of findings table, which was agreed on by all authors. ZAB contributed to the writing and interpretation of the findings. $E M-W$ is the guarantor.

Funding The authors received internal support from the Department of Epidemiology, Johns Hopkins Bloomberg School of Public Health (US); the Centre for Outcomes Research and Effectiveness (CORE), Research Department of Clinical, Educational \& Health Psychology, University College London (UK); the Centre for Evidence Based Intervention, Department of 
Social Policy and Intervention, University of Oxford (UK); and the Division of Women and Child Health, Aga Khan University Hospital (PK).

Competing interests $Z A B$ is an author of some of the included trials. $Z A B$ and $\mathrm{Al}$ have published previous reviews about zinc.

Provenance and peer review Not commissioned; externally peer reviewed.

Data sharing statement No additional data are available.

Open Access This is an Open Access article distributed in accordance with the Creative Commons Attribution Non Commercial (CC BY-NC 3.0) license, which permits others to distribute, remix, adapt, build upon this work noncommercially, and license their derivative works on different terms, provided the original work is properly cited and the use is non-commercial. See: http:// creativecommons.org/licenses/by-nc/3.0/

\section{REFERENCES}

1. Hotz C, Brown K; International Zinc Nutrition Consultative Group (IZiNCG). Assessment of the risk of zinc deficiency in populations and options for its control. Food Nutr Bull 2004;25(1 Suppl 2):S94-203.

2. Maggini S, Wenzlaff S, Hornig D. Essential role of vitamin $C$ and zinc in child immunity and health. $J$ Int Med Res 2010;38:386-414.

3. Black RE, Victora CG, Walker SP, et al. Maternal and child undernutrition and overweight in low-income and middle-income countries. Lancet 2013;382:427-51.

4. Aggarwal R, Sentz J, Miller MA. Role of zinc administration in prevention of childhood diarrhea and respiratory illnesses: a meta-analysis. Pediatrics 2007;119:1120-30.

5. Brown KH, Peerson JM, Baker SK, et al. Preventive zinc supplementation among infants, preschoolers, and older prepubertal children. Food Nutr Bull 2009;30:S12-40.

6. Imdad A, Bhutta ZA. Effect of preventive zinc supplementation on linear growth in children under 5 years of age in developing countries: a meta-analysis of studies for input to the lives saved tool. BMC Public Health 2011;11(Suppl 3):S22.

7. Patel $A B$, Mamtani $M$, Badhoniya $N$, et al. What zinc supplementation does and does not achieve in diarrhea prevention: a systematic review and meta-analysis. BMC Infect Dis 2011;11:122.

8. Ramakrishnan U, Nguyen $P$, Martorell R. Effects of micronutrients on growth of children under 5 y of age: meta-analyses of single and multiple nutrient interventions. Am J Clin Nutr 2009;89:191-203.

9. Roth DE, Richard SA, Black RE. Zinc supplementation for the prevention of acute lower respiratory infection in children in developing countries: meta-analysis and meta-regression of randomized trials. Int J Epidemiol 2010;39:795-808.

10. Yakoob MY, Theodoratou E, Jabeen A, et al. Preventive zinc supplementation in developing countries: impact on mortality and morbidity due to diarrhea, pneumonia and malaria. (Special issue: technical inputs, enhancements and applications of the Lives Saved Tool (LiST)). BMC Public Health 2011;11(Suppl 3):S23.

11. Bhutta ZA, Black RE, Brown KH, et al. Prevention of diarrhea and pneumonia by zinc supplementation in children in developing countries: pooled analysis of randomized controlled trials. Zinc Investigators' Collaborative Group. J Pediatr 1999;135:689-97.

12. Lassi ZS, Haider BA, Bhutta ZA. Zinc supplementation for the prevention of pneumonia in children aged 2 months to 59 months. Cochrane Database Syst Rev 2010;(12):CD005978.
13. Pasricha S-R, Hayes E, Kalumba K, et al. Effect of daily iron supplementation on health in children aged 4-23 months: a systematic review and meta-analysis of randomised controlled trials. Lancet Global Health 2013;1:e77-86.

14. Junior JA, Dean S, Mayo-Wilson E, et al. Zinc supplementation for preventing mortality and morbidity, and promoting growth, in children aged 6 months to 12 years of age (protocol). Cochrane Database Syst Rev 2011;10:CD009384.

15. Higgins JP, Green S. Cochrane handbook for systematic reviews of interventions. Version 5.1.0 [updated March 2011]. The Cochrane Collaboration, 2011.

16. Balshem $\mathrm{H}$, Helfand $\mathrm{M}$, Schunemann $\mathrm{HJ}$, et al. GRADE guidelines: 3. Rating the quality of evidence. J Clin Epidemiol 2011;64:401-6.

17. Bhandari N, Taneja S, Mazumder S, et al. Adding zinc to supplemental iron and folic acid does not affect mortality and severe morbidity in young children. $J$ Nutr 2007;137:112-17.

18. Sazawal S, Black RE, Ramsan $M$, et al. Effects of routine prophylactic supplementation with iron and folic acid on admission to hospital and mortality in preschool children in a high malaria transmission setting: community-based, randomised, placebo-controlled trial. [Erratum appears in Lancet 2006;367:302] Lancet 2006;367:133-43.

19. Tielsch JM, Khatry SK, Stoltzfus RJ, et al. Effect of routine prophylactic supplementation with iron and folic acid on preschool child mortality in southern Nepal: community-based cluster-randomised, placebo-controlled trial. Lancet 2006;367:144-52

20. Sempertegui F, Estrella B, Correa $E$, et al. Effects of short-term zinc supplementation on cellular immunity, respiratory symptoms, and growth of malnourished Equadorian children. Eur J Clin Nutr 1996;50:42-6.

21. Alarcon K, Kolsteren PW, Prada AM, et al. Effects of separate delivery of zinc or zinc and vitamin A on hemoglobin response, growth, and diarrhea in young Peruvian children receiving iron therapy for anemia. Am J Clin Nutr 2004;80:1276-82.

22. Mazariegos M, Hambidge KM, Westcott JE, et al. Neither a zinc supplement nor phytate-reduced maize nor their combination enhance growth of 6- to 12-month-old Guatemalan infants. J Nutr 2010;140:1041-8.

23. Duval S, Tweedie R. Trim and fill: a simple funnel-plot-based method of testing and adjusting for publication bias in meta-analysis. Biometrics 2000;56:455-63.

24. Wessells KR, Brown KH. Estimating the global prevalence of zinc deficiency: results based on zinc availability in national food supplies and the prevalence of stunting. PLOS ONE 2012;7:e50568.

25. Maret $\mathrm{W}$, Sandstead $\mathrm{HH}$. Zinc requirements and the risks and benefits of zinc supplementation. J Trace Elem Med Biol 2006;20:3-18.

26. Sandstrom B. Micronutrient interactions: effects on absorption and bioavailability. Br J Nutr 2001;85(Suppl 2):S181-5.

27. Ram U, Jha P, Ram F, et al. Neonatal, 1-59 month, and under-5 mortality in 597 Indian districts, 2001 to 2012: estimates from national demographic and mortality surveys. Lancet Global Health 2013;1:e219-e226.

28. Bhutta ZA, Das JK, Rizvi A, et al. Evidence-based interventions for improvement of maternal and child nutrition: what can be done and at what cost? Lancet 2013;382:452-77.

29. Wazny K, Zipursky A, Black R, et al. Setting research priorities to reduce mortality and morbidity of childhood diarrhoeal disease in the next 15 years. PLoS Med 2013;10:e1001446. 